\title{
Extinction of the Edinburgh lineage of the allopolyploid neospecies, Senecio cambrensis Rosser (Asteraceae)
}

\author{
RJ Abbott and DG Forbes \\ Harold Mitchell Building, Division of Environmental and Evolutionary Biology, School of Biology, University of St Andrews, Fife, \\ UK
}

\begin{abstract}
Senecio cambrensis is a new allopolyploid species, which originated independently in North Wales and in Edinburgh, Scotland. Despite extensive searches, the species has not been found growing at any of its previously recorded sites in Edinburgh or at other potential sites in the area since 1993. We have concluded that the Edinburgh lineage of $S$.
\end{abstract}

Keywords: allopolyploidy; plant speciation; species extinction; Senecio cambrensis; Asteraceae

New allopolyploid species are of considerable interest to evolutionary biologists because their parentage can be readily deduced and their ecological and evolutionary development be monitored from an early stage, thus providing important information on speciation via allopolyploidy and the establishment and spread of new plant species. Moreover, because new allopolyploids can arise repeatedly (Soltis and Soltis, 1993), it is possible to examine the success or failure of different independently arisen lineages and the causes of why some are more successful at becoming established.

Senecio cambrensis $(2 n=60)$, the Welsh ragwort, is one of four flowering plants known to have originated via allopolyploidy and to have become established in the wild in recent times, ie within the last 100 years or so (Ashton and Abbott, 1992; Soltis and Soltis, 1993). It is an annual or short-lived perennial herb, which colonises open, disturbed ground and also crevices in walls and pavements (Ingram and Noltie, 1995). The species is endemic to the British Isles and was first recorded in North Wales in 1948 (Rosser, 1955). It is believed to have originated there sometime between 1910 and 1948 (Ashton and Abbott, 1992). It was later discovered in Edinburgh in 1982 (Abbott et al, 1983a, b), where it is now known to have been present since at least 1974 (Abbott et al, 1983a, b). Surveys of allozyme and chloroplast DNA variation (Ashton and Abbott 1992; Harris and Ingram, 1992; Lowe and Abbott, 1996) confirmed that S. vulgaris $(2 \mathrm{n}=40)$ and $S$. squalidus $(2 \mathrm{n}=20)$ are the parents of $S$. cambrensis and that the new species had originated independently in Edinburgh and Wales.

Since the discovery of the Edinburgh form of S. cam-

Correspondence: $R$ Abbott, Harold Mitchell Building, Division of Environmental and Evolutionary Biology, School of Biology, University of St Andrews, St Andrews, Fife KY16 9TH, UK.

E-mail: rja@st-andrews.ac.uk

Received 20 July 2001; accepted 6 November 2001 cambrensis is now extinct and discuss possible causes of its extinction. The lineage was present in Edinburgh from at least 1974 and therefore survived in the wild for a minimum of 19 years. The species remains well established in parts of North Wales.

Heredity (2002) 88, 267-269. DOI: 10.1038/sj/hdy/6800038 brensis, we have monitored its presence each year (until July 2001) at sites where it was first recorded in Edinburgh (Abbott et al, 1983b), and other potential sites, ie wasteground, walls and roadsides, in the surrounding area. The species has not been found growing at any of these sites since 1993 when three mature individuals, each producing good seed, were recorded in late April on wasteground at Coal Hill, Leith (Table 1). In view of the species absence from all Edinburgh sites examined over the past 8 years, we have concluded that it no longer occurs there and that the Edinburgh lineage has become extinct. It is unlikely that the lineage persists as dormant seed in the area, as seeds of both progenitors exhibit only limited persistence in the soil (Roberts, 1964; Grime et al, 1988)

Levin (2000) has outlined various factors likely to cause the extinction of a new plant species in the wild. When an allopolyploid neospecies occurs at sites in low numbers relative to its progenitors, which is normally the case at early stages of establishment, there is a high chance of it rapidly becoming extinct. Under these conditions, the neospecies can suffer from various forms of minority type disadvantage. For example, if a new allopolyploid species is not ecologically differentiated from its progenitors and therefore occupies the same habitat as one or both of them, it is likely to be out-competed from locations where it co-occurs with its more abundant parents (Levin 2000, and references therein p 164). Moreover, in metapopulations, the increased number of offspring per individual produced by progenitors relative to the competitively inferior neospecies will place the neospecies at a significant disadvantage in colonising open-sites within dispersal range. In Edinburgh, S. cambrensis only occurred at sites and at times of the year where one or both of its progenitors were present in greater abundance (personal observation). Consequently, the Edinburgh lineage most likely suffered competition from its progenitors (and also from other species) and, in 
Table 1 Number of mature plants of S. cambrensis on sites in Leith, Edinburgh, from 1982 until 1994. Sites 1-6 are the same as those listed in Abbott et al, 1983b (X indicates sites that were completely re-developed during the period and no longer available for colonisation)

Sites

Date of survey (month/year)

\begin{tabular}{|c|c|c|c|c|c|c|c|c|c|c|c|c|c|}
\hline & $9 / 82$ & $6 / 83$ & $6 / 84$ & $6 / 85$ & $6 / 86$ & $6 / 87$ & $6 / 88$ & $6 / 89$ & 9/90 & $5 / 91$ & $6 / 92$ & $4 / 93$ & $6 / 94$ \\
\hline 1. Bangor Road (wasteground) & 25 & $\mathrm{X}$ & $X$ & $\mathrm{X}$ & $\mathrm{X}$ & $\mathrm{X}$ & $\mathrm{X}$ & $\mathrm{X}$ & $\mathrm{X}$ & $\mathrm{X}$ & $\mathrm{X}$ & $\mathrm{X}$ & $\mathrm{X}$ \\
\hline 2. Sheriff Brae (pavement cracks and joints) & 43 & 19 & 5 & 2 & 0 & 0 & 0 & 0 & 0 & 0 & 0 & 0 & 0 \\
\hline 3. Coal Hill (factory yard) & 4 & 2 & 0 & 0 & 1 & 1 & 0 & 0 & $X$ & $\mathrm{X}$ & $X$ & $\mathrm{X}$ & $\mathrm{X}$ \\
\hline 4. Broad Wynd (wasteground) & 19 & 2 & 1 & $\mathrm{X}$ & $\mathrm{X}$ & $X$ & $\mathrm{X}$ & $\mathrm{X}$ & $\mathrm{X}$ & $\mathrm{X}$ & $\mathrm{X}$ & $\mathrm{X}$ & $\mathrm{X}$ \\
\hline 5. Tolbooth Wynd (wasteground) & 3 & $X$ & $X$ & $X$ & $X$ & $X$ & $\mathrm{X}$ & $x$ & $\mathrm{X}$ & $\mathrm{X}$ & $\mathrm{X}$ & $X$ & $X$ \\
\hline 6. Salamander $\mathrm{St}^{\mathrm{a}}$ (wasteground) & 8 & 14 & 13 & 15 & 33 & 13 & 17 & 2 & 1 & 0 & 0 & 0 & 0 \\
\hline 7. Coal Hillb (river embankment/wasteground) & - & 23 & 20 & 23 & 22 & 15 & 9 & 3 & 3 & 2 & 2 & 3 & 0 \\
\hline Total & 102 & 60 & 39 & 40 & 56 & 29 & 26 & 5 & 4 & 2 & 2 & 3 & 0 \\
\hline
\end{tabular}

${ }^{a}$ Most of this site was built on in 1989, leaving only the margins available for colonisation

bWasteground adjacent to this site was developed from 1988 onwards, while the river embankment became overgrown largely with S. squalidus.

turn, would have been less effective at colonising new sites.

Another form of minority type disadvantage occurs when an allopolyploid neospecies reproduces by outcrossing in sympatry with one or both parents (Levin, 1975; Felber, 1991). Under these conditions most of its offspring will be produced from crosses with a progenitor and exhibit low fitness. Offspring of crosses between S. cambrensis and S. squalidus are very infertile (Ingram and Noltie, 1995), while the cross with S. vulgaris produces pentaploid offspring that are vigorous, but have reduced seed set (Ingram and Noltie, 1995). However, because $S$. cambrensis is self-compatible and exhibits low outcrossing in the wild (Ingram and Noltie, 1995), most of its offspring will be non-hybrid and, consequently, the species will not suffer much, if at all, from this minority type disadvantage. Also, because S. cambrensis produces inconspicuous flower heads, it is unlikely to receive much cross-pollen from either progenitor and should not, therefore, be subject to pollen germination and/or pollen tube interference from them (see Levin, 2000).

Even if a neospecies were ecologically differentiated from its progenitor(s), the fact that it occurs at very low numbers during the early stage of establishment will put it at considerable risk of going extinct due to environmental and demographic perturbations (Shaffer, 1987; Lande, 1988). It is crucial for a neospecies to expand rapidly the numbers and sizes of its populations to avoid this risk of extinction. When S. cambrensis was first discovered in Edinburgh in 1982, it was found at six different sites that were all within a distance of $1.2 \mathrm{~km}$ of each other (Table 1). The total number of individuals recorded was 102 with stands of 43, 25, and 19 individuals occurring at three of the sites, respectively. Since this time, most sites have been built on or become overgrown by more competitive plants. Only one site, at Sheriff Brae, has remained virtually unchanged, but is now occupied entirely by the progenitor species and other species associated with early stages of colonisation. During the same period, there has been a reduction in the number of available sites for colonisation in the immediate area. In the 1970s and early 1980s huge populations of S. vulgaris and S. squalidus were regularly found in the area on land that had been cleared prior to development (Marshall and Abbott, 1980, 1982). Such populations have not been evi- dent in recent years (personal observation) as the scale of redevelopment has decreased and suitable wasteground for colonisation has become significantly reduced. From 1982 to 1993 the number of individuals of S. cambrensis steadily declined in the area, in parallel with a decrease in available sites for colonisation (Table 1). Maintenance of S. cambrensis in Edinburgh is likely to have depended crucially, on the continued availability of large areas of open habitat, which the species could colonise. Once such areas of land were no longer available, the probability of extinction of the Edinburgh lineage of $S$. cambrensis is likely to have increased significantly.

We can estimate that the Edinburgh lineage survived in the wild for a minimum of 19 years, ie from at least 1974 until 1993. Although now extinct in Edinburgh, S. cambrensis remains well established in Wales where it has expanded its geographical range in recent years and forms large populations at several locations (Ingram and Noltie, 1995). It would be of interest to examine the factors that have favoured the species' establishment in this part of Britain.

\section{References}

Abbott RJ, Ingram R, Noltie HJ (1983a). Discovery of Senecio cambrensis Rosser in Edinburgh. Watsonia 14: 407-408.

Abbott RJ, Noltie HJ, Ingram R (1983b). The origin and distribution of Senecio cambrensis Rosser in Edinburgh. Trans Bot Soc Edinb 44: 103-106.

Ashton PA, Abbott RJ (1992). Multiple origins and genetic diversity in the newly arisen allopolyploid species, Senecio cambrensis Rosser, (Compositae). Heredity 68: 25-32.

Felber F (1991). Establishment of a tetraploid cytotype in a diploid population: effect of the relative fitness of the cytotypes. I Evol Biol 4: 195-207.

Grime JP, Hodgson JG, Hunt R (1988). Comparative Plant Ecology. Unwin Hyman: London.

Harris SA, Ingram R (1992). Molecular systematics of the genus Senecio L. I. Hybridization in a British polyploid complex. Heredity 69: 1-10.

Ingram R, Noltie HJ (1995). Senecio cambrensis Rosser, Biological Flora of the British Isles. J Ecol 83: 537-546.

Lande R (1988). Genetics and demography in biological conservation. Science 241: 1455-1460.

Levin DA (1975). Minority cytotype exclusion in local plant populations. Taxon 24: 35-43. 
Levin DA (2000). The Origin, Expansion and Demise of Plant Species. Oxford University Press: Oxford.

Lowe AJ, Abbott RJ (1996). Origins of the new allopolyploid species Senecio cambrensis (Asteraceae) and its relationship to the Canary Islands endemic Senecio teneriffae. Am J Bot, 83: 1365-1372.

Marshall DF, Abbott RJ (1980). On the frequency of introgression of the radiate $\left(T_{r}\right)$ allele from Senecio squalidus L. into Senecio vulgaris L. Heredity 45: 133-135.

Marshall DF, Abbott RJ (1982). Polymorphism for outcrossing frequency at the ray floret locus in Senecio vulgaris L. I. Evidence. Heredity 48: 227-235.
Roberts HA (1964). Emergence and longevity in cultivated soil of seed of some annual weeds. Weed Res 4: 296-307.

Rosser EM (1955). A new British species of Senecio. Watsonia 3: 228-232.

Shaffer M (1987). Minimum viable populations: coping with uncertainty. In: Soulé M (eds) Viable Populations for Conservation, Cambridge University Press: Cambridge. pp 69-86.

Soltis DE, Soltis PS (1993). Molecular data and the dynamic nature of polyploidy. Crit Rev Pl Sci 12: 243-273. 